\title{
Pengaruh Pandemi Covid-19 Terhadap Pola Konsumsi Mahasiswa
}

\author{
${ }^{1}$ Alvina Putri Nabilah, ${ }^{2}$ Karima Nurul Fitri, ${ }^{3}$ Rahmi Kharisma Primastuti, ${ }^{4}$ Rifqa Tsania \\ Khoirunnisaa, ${ }^{5}$ Anju, ${ }^{6}$ Ernawati \\ Institut Teknologi Bandung \\ alvinapn@students.itb.ac.id
}

\begin{abstract}
Abstraksi.
Salah satu sektor yang terdampak pandemi COVID-19 adalah pendidikan. Institusi dihimbau untuk tidak melaksanakan kegiatan belajar mengajar secara langsung dengan tujuan mengurangi penyebaran COVID19 sehingga ditetapkan sistem pembelajaran jarak jauh. Hal tersebut berdampak pada pola konsumsi mahasiswa karena adanya perubahan terkait kebiasaan baru di masa pandemi. Penelitian ini merupakan penelitian kuantitatif, kualitatif, dan deskripsi dengan metode survei dan studi literatur. Kuesioner disampaikan melalui Jotform dengan total responden sebanyak 106 mahasiswa yang disebarkan melalui berbagai sosial media. Data yang didapatkan menunjukkan pengeluaran selama masa pandemi mengalami penurunan. Begitupun dengan biaya transportasi yang juga mengalami penurunan karena banyaknya aktivitas yang dilakukan di rumah. Sedangkan kebutuhan biaya internet selama masa pandemi menunjukkan peningkatan. Sehingga dapat disimpulkan bahwa perubahan pola konsumsi mahasiswa di masa pandemi memiliki pengaruh terhadap pola kehidupan mahasiswa, diantaranya terjadi peningkatan pada kebutuhan internet, penggunaan uang digital, dan kebiasaan berbelanja online, dan menunjukkan penurunan pada biaya transportasi, kebutuhan di tempat tinggal, dan kebutuhan kuliah. Hal ini disebabkan pola adaptasi manusia terhadap perubahan keadaan sosial ekonomi selama pandemi.
\end{abstract}

Kata kunci: Konsumsi, mahasiswa, pandemi.

\begin{abstract}
.
One of the sectors affected by the Covid-19 pandemic is education. Institutions are advised not to carry out direct teaching and learning activities with the aim of reducing the spread of Covid-19, hence an online learning system is established. This has an impact on college students' consumption patterns due to changes related to new habits during the pandemic. This research is a quantitative, qualitative, and descriptive study using survey methods and literature studies. The questionnaire was delivered through Jotform with a total of 106 college students as respondents and distributed through various social media. The data obtained shows that spending has decreased during the pandemic. Likewise, transportation expenses have also decreased due to many activities carried out at home. Meanwhile, the need for internet fees during the pandemic period shows an increase. It can be concluded that changes in college students' consumption patterns during the pandemic have an influence on their life patterns, including an increase in internet needs, use of digital money, and online shopping habits, but shows a decrease in transportation expenses, housing needs, and college needs. This is due to the pattern of human adaptation to changes in socio-economic conditions during the pandemic.
\end{abstract}

Keywords: College students, consumption, pandemic. 


\section{Pendahuluan}

Sejak tanggal 11 Maret 2020, wabah penyakit akibat virus COVID-19 telah ditetapkan sebagai pandemi global oleh organisasi kesehatan dunia atau WHO. Sebagai respon terhadap pandemi COVID-19 yang mewabah secara cepat, pemerintah Indonesia menerapkan pembatasan melalui kebijakan social distancing dengan menjaga jarak sosial dan menghindari kerumunan, serta physical distancing dengan menjaga jarak antar orang minimal 1,8 meter yang berlaku sejak awal Maret 2020. Salah satu dampak dari diterapkannya kebijakan tersebut adalah penurunan aktivitas dan pergerakan ekonomi masyarakat secara drastis di berbagai wilayah di Indonesia. Namun, himbauan pembatasan sosial dianggap kurang efektif dalam mencegah penularan COVID-19 sehingga pemerintah pusat akhirnya menerapkan Pembatasan Sosial Berskala Besar (PSBB). Dengan diterapkannya PSBB sebagian besar industri dan perkantoran dilarang beroperasi dalam jangka waktu yang cukup lama sehingga menimbulkan kerugian ekonomi (Hadiwardoyo, W. 2020).

Social distancing atau lockdown di Indonesia memiliki landasan hukum UU No. 6 Tahun 2018 yang berisi tentang Kekarantinaan Kesehatan. Kekarantinaan Kesehatan menurut UU tersebut adalah suatu upaya mencegah keluar masuknya penyakit yang berisiko terhadap kesehatan masyarakat yang berpotensi menimbulkan situasi darurat. Dalam UU No. 6 Tahun 2018, respon dari keadaan darurat kesehatan diantaranya adalah dilakukannya karantina rumah, karantina rumah sakit, karantina wilayah, dan termasuk yang digagas oleh presiden saat ini yaitu Pembatasan Sosial Berskala Besar atau PSBB. Respon-respon tersebut didasarkan pada pertimbangan epidemiologis, besarnya ancaman, efektifitas, dukungan sumber daya, teknis operasional, pertimbangan ekonomi, sosial, budaya, dan keamanan (Kartono, 2020).

Selain pada sektor ekonomi, transportasi, dan industri, pandemi COVID-19 juga berdampak bagi sektor pendidikan. Institusi-institusi pendidikan dihimbau untuk tidak melaksanakan kegiatan belajar-mengajar secara langsung dengan tujuan untuk mengurangi penyebaran COVID-19. Oleh karena itu, diterapkan sistem pembelajaran jarak jauh atau daring. Hal tersebut berdampak pada pola pengeluaran khususnya bagi mahasiswa yang disebabkan adanya perubahan terkait kebiasaan baru di masa pandemi sehingga memunculkan kebutuhan-kebutuhan baru. Bagi mahasiswa, himbauan untuk beraktivitas dari rumah selama pandemi COVID-19 menyebabkan adanya peningkatan maupun penurunan pengeluaran dalam hal-hal tertentu (Firman, 2020).

Konsumsi merupakan salah satu aktivitas masyarakat yang dipengaruhi oleh beberapa faktor meliputi pendapatan, lingkungan, dan kebutuhan. Masyarakat, individu, termasuk mahasiswa, memiliki pola konsumsi yang berbeda-beda. Bahkan pada mahasiswa, perbedaan pola konsumsi tersebut dapat terlihat dari perbedaan jurusan yang mereka ambil. Sebagai contoh, mahasiswa jurusan teknik atau kedokteran, akan lebih banyak mengeluarkan biaya untuk pembelian alat-alat praktikum dibandingkan dengan mahasiswa jurusan ekonomi atau sastra yang tidak melakukan praktikum. Lebih umum lagi, perbedaan konsumsi mahasiswa juga dapat dilihat dari perbedaan tempat tinggal, dimana jika tinggal bersama orang tua, pengeluaran biaya untuk konsumsi seharihari tentu akan lebih sedikit dibandingkan jika tinggal sendiri, baik di indekos maupun di asrama (Larasati, 2020).

Seperti yang sudah disebutkan sebelumnya, pembelajaran jarak jauh atau daring karena pandemi seperti sekarang ini tentu saja memengaruhi pola konsumsi mahasiswa. Hal ini dapat dilihat dengan jelas pada konsumsi internet yang dipastikan lebih besar jika dibandingkan dengan konsumsi internet sebelum pandemi. Contoh lainnya adalah pengeluaran biaya untuk transportasi yang kemungkinan akan mengalami penurunan karena tidak perlu pergi ke kampus untuk 
mengikuti perkuliahan. Perubahan pola konsumsi di kalangan mahasiswa ini harus disikapi secara bijak sehingga menjadi perhatian dari tim peneliti.

\section{Telaah Konsep}

\section{Pengaruh Pandemi COVID-19}

Virus Corona merupakan virus jenis SARS-CoV-2 yang menyebabkan penyakit Coronavirus Disease 2019 (COVID-19). Badan Kesehatan Dunia (WHO) secara resmi mendeklarasikan Virus Corona sebagai pandemi pada tanggal 9 Maret 2020. Menurut Kamus Besar Bahasa Indonesia (KBBI), istilah pandemi berarti wabah yang berjangkit serempak dimana-mana, meliputi daerah geografi yang luas. Dilansir dari laman web Covid19.go.id, virus corona pada umumnya menimbulkan gejala ringan hingga sedang seperti demam dan batuk yang kebanyakan dapat sembuh dalam beberapa minggu. Namun, bagi sebagian orang dengan resiko tinggi seperti kelompok lanjut usia dan orang dengan masalah kesehatan menahun, virus corona dapat menyebabkan masalah kesehatan yang serius.

Penyebaran virus corona dapat terjadi melalui kontak antar individu seperti melalui sentuhan, atau air liur. Hal tersebut menyebabkan pemerintah dari berbagai negara menerapkan kebijakan social distancing maupun physical distancing dengan tujuan untuk mencegah dan menghambat penyebaran COVID-19. Pemerintah menerapkan kebijakan untuk menutup tempat-tempat yang memungkinkan terjadinya kerumunan dan kontak fisik. Penerapan kebijakan tersebut menyebabkan sebagian besar industri dan perkantoran dilarang beroperasi dalam jangka waktu yang cukup lama sehingga menimbulkan kerugian ekonomi. Selain itu, penutupan sekolah, perguruan tinggi, dan institusi pendidikan lainnya menyebabkan kegiatan pembelajaran dan kegiatan yang bersifat administratif lainnya dilaksanakan secara jarak jauh (Firman, 2020).

\section{Pola Konsumsi Mahasiswa}

Pola adalah gambaran yang dipakai (Anwar, 2001), konsumsi adalah pemakaian barangbarang hasil industri (Anwar, 2001), dan mahasiswa adalah pelajar perguruan tinggi (Anwar, 2001). Pola konsumsi mahasiswa dapat diartikan sebagai gambaran pemakaian barang-barang hasil industri oleh pelajar perguruan tinggi. Pola konsumsi juga dapat diartikan sebagai berbagai macam informasi yang memberikan gambaran mengenai jenis, jumlah dan frekuensi produk yang digunakan oleh kelompok masyarakat tertentu (Baliwati, 2004). Faktor yang mempengaruhi pola konsumsi adalah besar pendapatan, tingkat harga, tingkat bunga, sosial ekonomi, selera, dan pengetahuan ekonomi yang dimiliki (Suparmono, 2004; Indrianawati \& Soesatyo, 2017). Subjek yang diamati pola konsumsinya pada penelitian ini adalah mahasiswa yang kuliah di Pulau Jawa, khususnya Kota Bandung, dan Pulau Sumatera.

\section{Metode.}

Penelitian ini merupakan metode penelitian survey deskriptif. Metode penelitian survei deskriptif akan menggambarkan fenomena yang terjadi dengan deskripsi secara sistematis, faktual, dan akurat mengenai fakta dan sifat populasi tertentu (Suryana, 2010). Populasi yang digunakan adalah mahasiswa di pulau Jawa dan Sumatera. Pencarian informasi untuk penelitian ini adalah survei dan studi literatur. Hal ini dilakukan untuk melihat modifikasi atau perubahan pola konsumsi mahasiswa sehingga dapat diketahui apa saja kebutuhan serta kemampuan mahasiswa dalam memenuhi kebutuhan tersebut. Tim peneliti membuat kuesioner yang disebar kepada mahasiswa dari berbagai kampus di pulau Jawa pada rentang 15-24 Maret 2021. Karena sedang berada dalam masa pandemi, kuesioner disampaikan melalui Jotform dengan total responden 
sebanyak 106 orang mahasiswa. Penyebaran menggunakan aplikasi sosial media, seperti line dan twitter.

Hasil dari survei direpresentasikan dengan menggunakan grafik. Grafik digunakan untuk mencari hasil terhadap tujuan dan menguji hasil survei tanpa perhitungan statistik sehingga dapat disimpulkan bahwa penelitian yang dilakukan adalah kualitatif (Suryana, 2010).

\section{Hasil dan Pembahasan.}

Pada survei dengan 106 responden didapatkan jawaban variatif untuk setiap pertanyaan. Pertanyaan data diri yang ditanyakan adalah nama, asal daerah, asal kampus, tingkat perkuliahan, dan status tempat tinggal. Asal daerah dari responden berada dari Jawa, Sumatera, dan Kalimantan. Asal kampus berada di Jawa dan Sumatera. Terdapat juga tingkat perkuliahan yang variatif. Terdapat $16,19 \%$ dari tingkat $1,62,86 \%$ dari tingkat $2,11,43 \%$ dari tingkat $3,7,62 \%$ dari tingkat 4 , serta $1,90 \%$ dari tingkat 5 atau selanjutnya. Responden sebanyak $68,87 \%$ tinggal bersama keluarga saat ini, $23,58 \%$ kost, dan 7,55\% asrama.

Untuk dapat mengetahui pola konsumsi mahasiswa selama pandemi maka diberikan pertanyaan mengenai pengeluaran konsumsi makanan selama sebulan, biaya transportasi selama sebulan, uang saku, pemenuhan kebutuhan sehari-hari, penggunaan uang elektronik, pengeluaran internet, pengeluaran lain, dan pendapatan lain dari beasiswa, kerja, atau lainnya.

\section{Pengeluaran Konsumsi Makanan Mahasiswa Selama Satu Bulan}

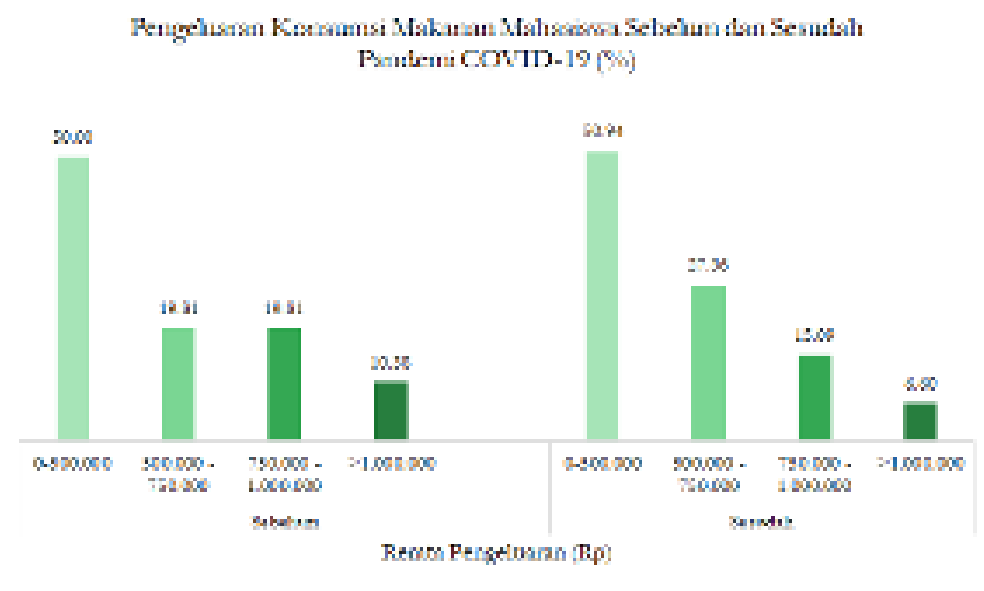

Gambar 1.1 Grafik hasil survei rerata pengeluaran konsumsi makanan mahasiswa per bulan sebelum dan sesudah adanya pandemi COVID-19

Dari data Gambar 1.1, pengeluaran konsumsi makanan mahasiswa sebelum dan sesudah pandemi mendapatkan perbedaan hasil yang cukup signifikan. Pada periode sebelum pandemi, jumlah pengeluaran responden terbanyak berada pada rentang $\mathrm{Rp} 0$ - Rp 500.000 dan pada periode pandemi, pengeluaran responden terbanyak pun berada pada rentang yang sama dengan persentase yang meningkat $0.94 \%$. Hal ini menunjukkan bahwa pada periode pandemi, pengeluaran mahasiswa menjadi menurun. Namun, pada rentang Rp 500.000 - Rp 750.000 terjadi kenaikan sedangkan untuk rentang yang lainnya mengalami penurunan. 


\section{Pengeluaran Biaya Transportasi Selama Satu Bulan}

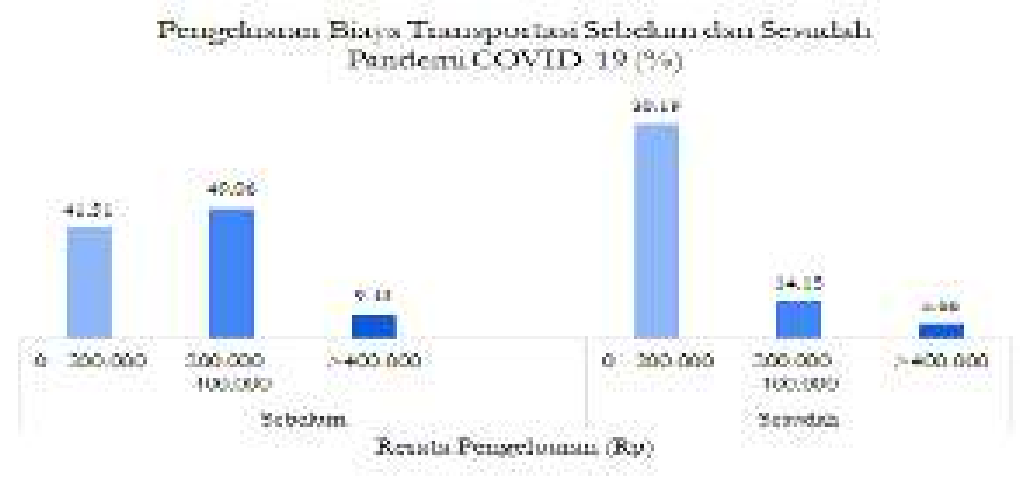

Gambar 1.2 Grafik hasil survei rerata pengeluaran biaya transportasi mahasiswa per bulan sebelum dan sesudah adanya pandemi COVID-19

Dari data pada Gambar 1.2, pengeluaran biaya transportasi sebelum dan sesudah pandemi mendapatkan perbedaan hasil yang cukup signifikan. Pada periode sebelum pandemi, jumlah pengeluaran responden terbanyak berada pada rentang Rp 200.000 - Rp400.000 sedangkan pada periode pandemi, pengeluaran responden terbanyak berada pada rentang Rp 0 - Rp 200.000 dengan persentase $80.19 \%$ dari persentase $49.06 \%$ sebelum masa pandemi. Hal ini menunjukkan bahwa saat pandemi, pengeluaran mahasiswa menjadi menurun. Penyebab penurunan biaya transportasi adalah PSBB. Akibat penyebaran pandemi yang sangat cepat, pemerintah menerapkan kebijakan untuk membatasi semua aktivitas publik dan kegiatan yang mengharuskan untuk keluar rumah, seperti sekolah, kuliah, kerja sekaligus ibadah serta membatasi akses pergerakan moda transportasi masyarakat ke luar kota dan sebaliknya. Salah satu dampak dari diberlakukannya kebijakan tersebut adalah penurunan jumlah penumpang transportasi umum termasuk mahasiswa (Talitha, 2020). Maka dapat diketahui bahwa kebijakan pemerintah terhadap pandemi COVID-19 dapat menurunkan mobilitas dari mahasiswa.

\section{Uang Saku Mahasiswa Selama Satu Bulan}

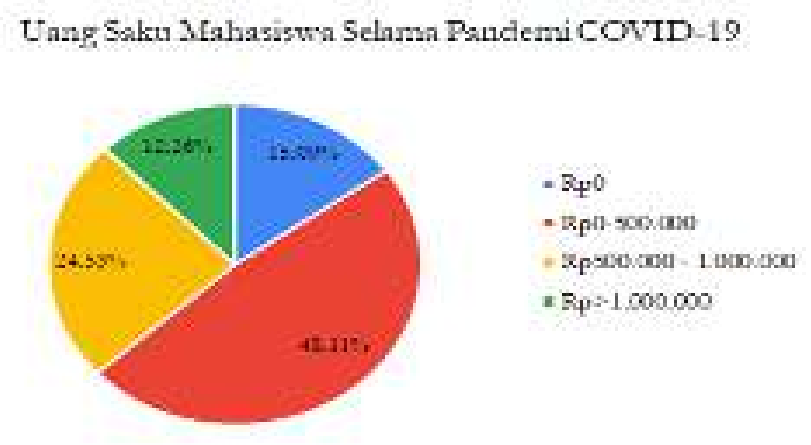

Gambar 1.3 Grafik hasil survei rerata uang saku mahasiswa per bulan selama pandemi COVID-19 
Dari data pada Gambar 1.3, mahasiswa paling banyak memiliki uang saku selama masa pandemi COVID-19 pada rentang Rp 0 - Rp 500.000. Uang saku tersebut didapatkan dari orang tua. Uang saku tersebut digunakan untuk membeli kebutuhan lain selama masa pandemi seperti kebutuhan kuliah, kebutuhan kerja, hobi, perawatan tubuh, sandang, organisasi, dan hiburan. Uang tersebut dapat berupa uang tunai maupun uang elektronik. Pada Gambar 2.6 terdapat 52.8\% responden dengan uang saku yang berkurang selama pandemi.

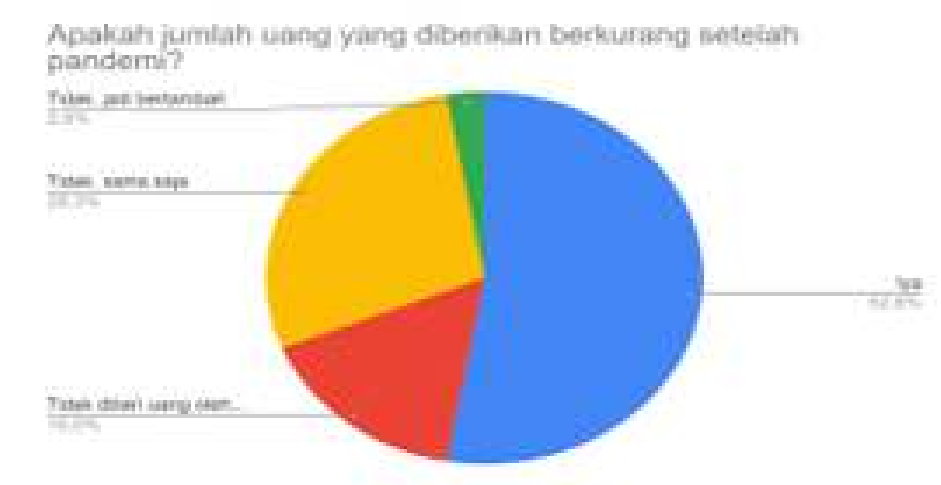

Gambar 2.6 Uang jajan yang diberikan setelah pandemi

\section{Pengeluaran Kebutuhan Sehari-hari dan Kebutuhan Lain, Serta Penggunaan Uang Elektronik Mahasiswa}

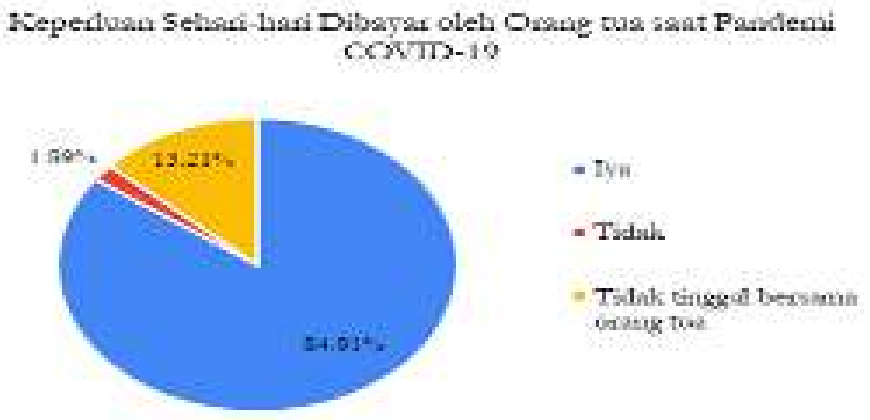

Gambar 1.4 Grafik hasil survei apakah kebutuhan sehari-hari (contoh: makanan pokok, listrik, air, Wifi, d11.) mahasiswa per bulan selama pandemi COVID-19 dibayar oleh orang tua atau tidak

Dari data pada Gambar 1.4, keperluan sehari-hari seperti tempat tinggal, makanan, minuman, listrik, air, dan Wifi sebagian besar dibayar oleh orang tua. Hal ini terjadi karena mahasiswa yang merantau untuk menuntut ilmu dapat kembali ke kampung halaman atau rumah tempat tinggal orang tua akibat kuliah daring. Kuliah daring menyebabkan mahasiswa tidak perlu berada di kota universitas itu berada. Selama tinggal bersama orang tua kebutuhan sehari-hari mahasiswa ditanggung oleh orang tua. Oleh sebab itu, pengeluaran mahasiswa untuk kost, makanan, minuman, listrik, air, dan Wifi menjadi berkurang. 


\section{Menjadj Lebih Sering Memakai Uang Elektronik Saat \\ Pandemi COVID-19}

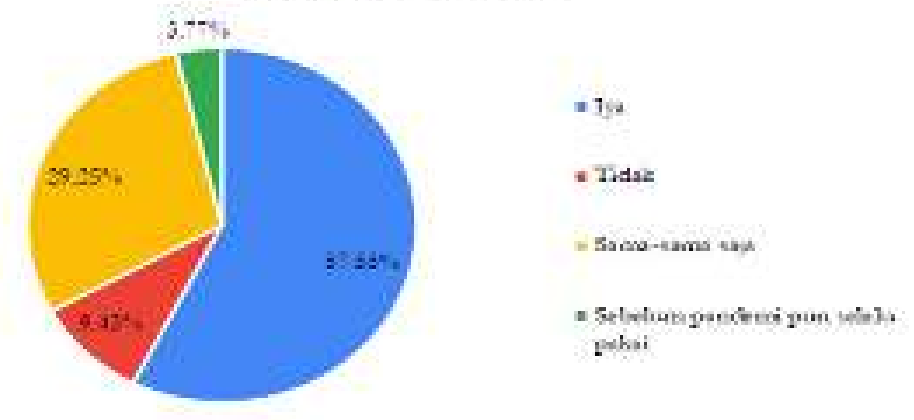

Gambar 1.5 Grafik hasil survei apakah mahasiswa menjadi lebih sering menggunakan uang elektronik atau tidak selama pandemi COVID-19

Dari data pada Gambar 1.5, pemakaian dari uang elektronik saat pandemi COVID-19 meningkat sebanyak $57.55 \%$. Peningkatan penggunaan uang elektronik terjadi karena penularan dari virus COVID-19 yang menyebar secara contagious. Istilah tersebut mengacu pada infeksi yang menyebar secara cepat dalam sebuah jaringan. Penyebaran virus secara contagious adalah penyebaran melalui elemen yang saling terhubung dalam jaringan sehingga dapat menularkan infeksi (Mona; 2020). Dalam hal ini dapat diartikan sebagai kontak atau sentuhan secara fisik. Hal ini menyebabkan penggunaan uang elektronik dibutuhkan agar efektif saat pembayaran, tidak membutuhkan kontak fisik, dan cepat agar tidak terjadi kerumunan di kasa pembayaran. Selain itu penggunaan uang elektronik juga dapat dipakai untuk belanja online dan belanja menggunakan aplikasi ojek online. Belanja online dan pembelian menggunakan ojek online menjadi sering dilakukan karena perkembangan teknologi yang menyediakan efisiensi dan kenyamanan dalam transaksi (Edgar; 2021).

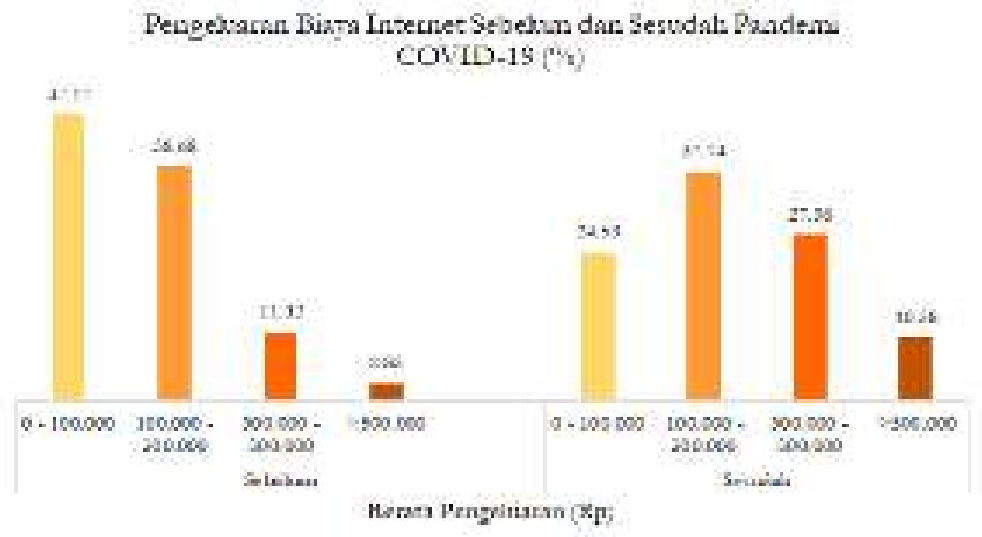

Gambar 1.6 Grafik hasil survei rerata pengeluaran kebutuhan internet mahasiswa per bulan sebelum dan sesudah adanya pandemi COVID-19

Data kebutuhan biaya internet sebelum dan selama masa pandemi pada Gambar 1.6 menunjukkan peningkatan. Hal ini dapat dilihat dari grafik yang mengalami peningkatan pesat pada rentang biaya $\mathrm{Rp} 100.000$ - Rp300.000. Selain itu, peningkatan kebutuhan internet selama pandemi didorong dengan aktivitas yang sebagian besar berbasis daring dan memerlukan koneksi 
internet. Sejalan dengan berbagai aktivitas berbasis daring yang dikerjakan di rumah, biaya transportasi mahasiswa tentu mengalami penurunan, sesuai dengan data pada Gambar 1.7.

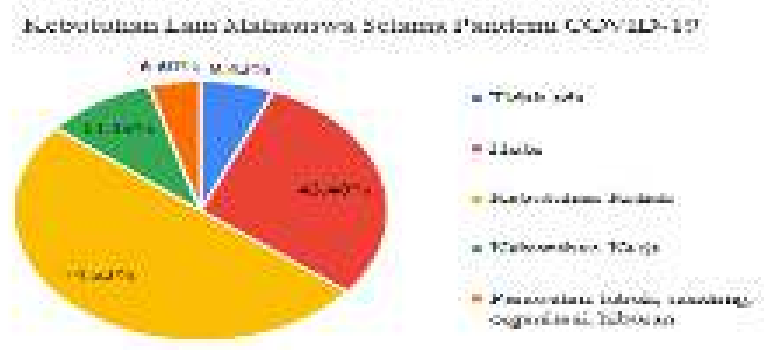

Gambar 1.7 Grafik hasil survei kebutuhan mahasiswa selain makanan, transportasi, dan internet selama pandemi COVID-19

Berdasarkan data pada Gambar 1.7 pengeluaran kebutuhan lain selama pandemi yang paling besar adalah dari kebutuhan kuliah dengan perolehan $74.53 \%$. Hal ini terjadi karena aturan dari kemendikbud yang memberhentikan sementara pembelajaran luring atau tatap muka sehingga kegiatan perkuliahan dilaksanakan secara daring atau jarak jauh. Dampak yang ditimbulkan antara lain peningkatan pengeluaran untuk biaya pulsa online untuk memfasilitasi kuliah daring. Selain itu, terdapat keterbatasan bagi mahasiswa yang sedang menyusun skripsi, melakukan riset lapangan, kegiatan praktikum laboratorium dan tugas-tugas lainnya (Indrawat; 200). Maka untuk kegiatan seperti praktikum harus membeli alat dan bahan secara pribadi dengan uang pribadi.

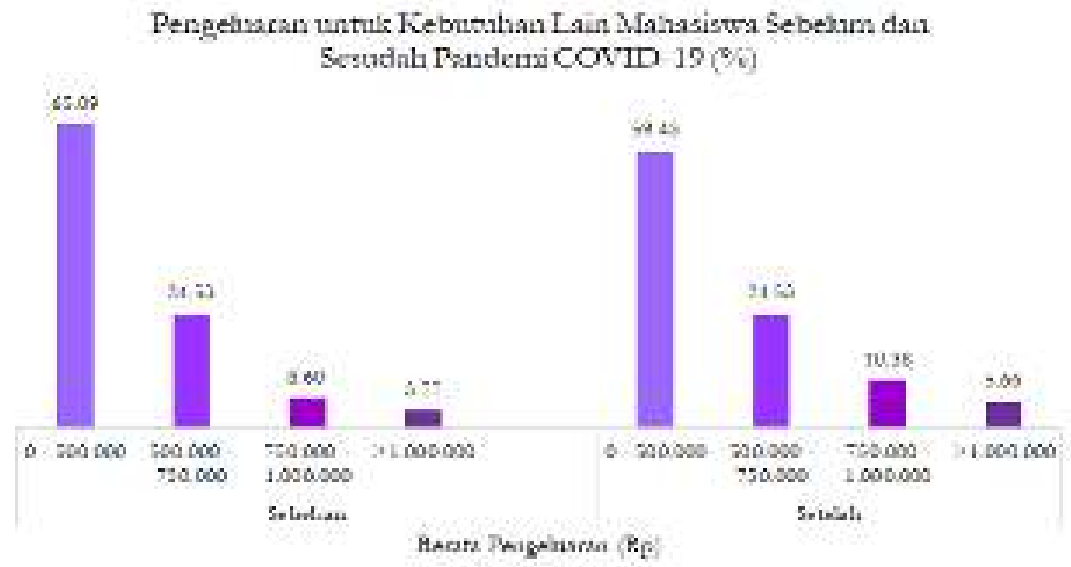

Gambar 1.8 Grafik hasil survei pengeluaran untuk kebutuhan mahasiswa selain makanan, transportasi, dan internet sebelum dan sesudah adanya pandemi COVID-19

Berdasarkan data pada Gambar 1.8 pengeluaran untuk kebutuhan lain seperti hobi, kebutuhan kuliah, kebutuhan kerja, perawatan tubuh, sandang, papan, organisasi, dan hiburan sebelum dan selama masa pandemi menunjukkan peningkatan. Hal ini dapat dilihat dari grafik yang mengalami peningkatan pesat pada pada rentang biaya Rp 750.000 - Rp.1.000.000 dan lebih dari Rp 1.000.000. Dalam setiap bulan pengeluaran mahasiswa termasuk konsumtif untuk pengeluaran makanan, aktivitas penunjang kuliah, fashion, hiburan dan laundry sedangkan pengeluaran tidak konsumtifnya adalah dalam hal komunikasi dan transportasi dengan pola konsumsi masing-masing berkisar $30 \%, 15 \%, 5 \%, 5 \%, 15 \%, 10 \%$ dan 20\%. Selain itu, pola konsumsinya dipengaruhi oleh 
tiga faktor utama yakni tempat tinggal, kepemilikan dapur di kost atau kontrakan dan di pondok, serta kegiatan perkuliahan (Nuriyantio; 2019).

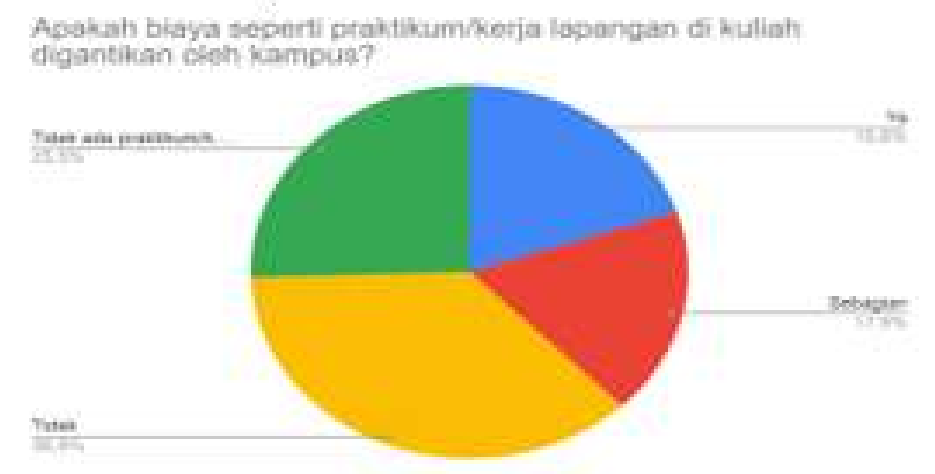

Gambar 2.7 Penggantian Biaya

Pada Gambar 2.7 biaya untuk keperluan kuliah seperti praktikum tidak dibayarkan kembali oleh kampus responden sebanyak 36.8\%. Pada peringkat kedua adalah hobi dengan perolehan $43.40 \%$. Hal ini terjadi karena selama masa pandemi harus menjalankan protokol COVID-19 agar dapat memutus rantai penyebaran virus. Protokol yang dilakukan adalah 3M, yaitu memakai masker, menjaga jarak, dan mencuci tangan menggunakan sabun (Raditya, Iswara ; 2021). Selain itu, masyarakat juga dianjurkan untuk melakukan aktivitas di rumah dan hanya keluar rumah jika dalam keadaan mendesak. Oleh sebab itu, salah satu cara untuk menghabiskan waktu selama di rumah adalah dengan melakukan hobi.

\section{Kesimpulan.}

Dalam penelitian ini didapatkan bahwa perubahan pola konsumsi pada mahasiswa yang berkuliah di Pulau Jawa dan Pulau Sumatera di masa pandemi memiliki pengaruh terhadap pola kehidupan mahasiswa. Hal ini dapat dibuktikan dengan adanya perubahan kebutuhan biaya yang meningkat meliputi kebutuhan internet, kebutuhan penggunaan aplikasi uang digital, dan belanja online namun memiliki hasil yang berbanding terbalik pada kebutuhan konsumsi makanan, biaya transportasi, dan pengeluaran biaya tempat tinggal seperti di indekos dan asrama. Hal tersebut disebabkan oleh pola adaptasi manusia terhadap perubahan keadaan sosial ekonomi selama periode pandemi.

Pandemi COVID-19 tak hanya berdampak pada mahasiswa namun masyarakat secara luas karena permasalahan yang ditimbulkan saling berhubungan satu sama lain. Contohnya peningkatan atau penurunan konsumsi mahasiswa akan berdampak pula pada pedagang atau produsen barang dan jasa. Dengan adanya pandemi, masyarakat "terpaksa" beralih pada gaya hidup yang lebih sering bersinggungan dengan teknologi, sehingga akan muncul suatu dorongan untuk menciptakan inovasi baru yang dapat menyediakan kebutuhan secara efisien.

\section{Daftar Pustaka.}

Anwar, Dessy. 2001. Kamus Lengkap Bahasa Indonesia. Surabaya: Karya Abditama Surabaya.

Baliwati, Y. K., Khomsan, A., dan Dwirianti, C. M. 2004. Pengantar Pangan dan Gizi. Jakarta: Penebar Swadaya.

Firman. "Dampak Covid-19 Terhadap Pembelajaran di Perguruan Tinggi". BIOMA. Vol. 2 No.1. 2020. Pp. 14-20. 
Hadiwardoyo, W.. "Kerugian Ekonomi Nasional Akibat Pandemi Covid-19". Baskara : Journal of Business and Entrepreneurship. Vol. 2 No.2. 2020. Pp. 83-92.

Indrawati, B. "Tantangan Dan Peluang Pendidikan Tinggi Dalam Masa Dan Pasca Pandemi Covid-19". Jurnal Kajian Ilmiah (JKI). Edisi Khusus No. 1. 2020. Pp. 39-48

Indrianawati, E., Soesatyo, Y. "Pengaruh Tingkat Pendapatan dan Pengetahuan Ekonomi Terhadap Tingkat Konsumsi Mahasiswa Program Pascasarjana Universitas Negeri Surabaya". Jurnal Ekonomi Pendidikan dan Kewirausahaan. Vol. 3 No. 2. 2017. Pp. 214226.

Kartono. "Pembatasan Sosial Berskala Besar (PSBB) Dan Pidana Denda Dalam Rangka Pencegahan dan Pemberantasan Pandemi Coronavirus Disease (Covid)-19". SALAM: Jurnal Sosial \& Budaya Syar'i. Vol. 7 No. 8. 2020. Pp. 687-694.

Larasati, R. A. "Pola Konsumsi Mahasiswa Pulang Kampung dan Masyarakat pada Pandemi COVID-19 di Kota Bandung". Jambura Economic Education Journal. Vol. 2 No.2. 2020. Pp. 90-99

Luthfiyah, Talitha Sahda. "Pengaruh COVID-19 Terhadap Transportasi Di Daerah Jabodetabek", Jurnal Mahasiswa Teknik Sipil Universitas Bung Hatta Padang. 2020. Pp.

2

Mona, N. Konsep Isolasi Dalam Jaringan Sosial Untuk Meminimalisasi Efek Contagious (Kasus Penyebaran Virus Corona di Indonesia)". Jurnal Sosial Humaniora Terapan. Vol. 2 No 2. 2020. Pp. 117-125

Nuriyantio, Muhammad Zaid. "Analisis Pola Konsumsi dan Gaya Hidup Mahasiswa Pendidikan Geografi JEMBER ANGKATAN 2018", Jurnal Kajian Ilmiah Majalah Pembelajaran

Geografi

Vol. 2 No. 2. 2019. ISSN 2622-125X

Permana, A. E., Reyhan, A. M., Rafli, H., Rakhmawati, N. A. "Analisa Transaksi Belanja Online pada Masa Pandemi COVID-19". Jurnal TEKNOINFO. Vol. 15 No. 1. 2021. Pp. 32 - 37.

Raditya, Iswara N. October 2 $2^{\text {nd }} .2020$. "Apa itu 3M untuk Mencegah \& Menekan Penularan Virus COVID-19?" Dapat diakses di: https://tirto.id/apa-itu-3m-untuk-mencegahmenekan-penularan-virus-covid-19-f5tV. Accessed on April 28 ${ }^{\text {th }}, 2021$.

Suparmono. 2004. Pengantar Ekonomi Makro : Teori, Soal, dan Penyelesaiannya. Yogyakarta: UPP AMP YKPN.

Suryana. 2010. METODOLOGI PENELITIAN : Model Praktis Penelitian Kuantitatif dan Kualitatif. Bandung: Universitas Pendidikan Indonesia. 